\title{
David Hume, the Académie des inscriptions and the Nature of Historical Evidence in the Early Eighteenth Century
}

\author{
Pedro Faria* \\ Hughes Hall, University of Cambridge \\ *Corresponding author. E-mail: pv301@cam.ac.uk
}

Philosophical history became the Enlightenment genre of historical writing par excellence supposedly by "defeating" established humanist erudite history and antiquarianism. This article argues that, contrary to established perceptions, philosophical history developed out of a concern expressed by early eighteenth-century erudite historians about the nature of historical evidence: both David Humeleading philosophical historian-and the members of the French erudite Académie des inscriptions et belles lettres shared a broadly Lockean approach to historical evidence, choosing verisimilitude to common experience as the key criterion of certainty. Indeed, Hume likely drew directly from the académiciens. Historical certainty is achieved, both sides concluded, by providing a verisimilar chain of causes of historical events, rather than mere lists of historical facts. Philosophical historians like Hume departed from the reformulated eighteenth-century version of erudite history by making causes the main object of history rather than merely a foundation of trustworthy factual accounts.

David Hume and the historians of the French Académie des inscriptions et belles lettres are not characters one expects to find together in a history of eighteenth-century historiography. Erudite history, philology, numismatics and diplomatics - the main businesses of the leading erudite academy of Hume's time-are not usually considered by current interpretations to be relevant to Hume's work or even to his context. Indeed, according to the established narrative about early eighteenth-century historiography, Hume and the académiciens were on opposite sides of a divide between the then nascent philosophical history and old antiquarianism and erudite history. ${ }^{1}$ This narrative was set in stone in 1950 by Arnaldo Momigliano, but as he and others have shown, it can be traced back to

\footnotetext{
${ }^{1}$ Historiography before the rise of philosophical history in the early eighteenth century can be divided into roughly two genres of historical writing: erudite history, which paid close attention to historical sources and focused on providing a complete and accurate account of past facts, and political history, which emphasized the actions of great political actors, trying to distil moral and political maxims from events of the past. Philosophical history, a genre associated with Enlightenment thinkers such as Hume, Montesquieu and Voltaire, had "society" and its political, economic and social institutions as its main object.

(c) Cambridge University Press 2020. This is an Open Access article, distributed under the terms of the Creative Commons Attribution-NonCommercial-NoDerivatives licence (http://creativecommons.org/licenses/by-nc-nd/4.0/), which permits non-commercial re-use, distribution, and reproduction in any medium, provided the original work is unaltered and is properly cited. The written permission of Cambridge University Press must be obtained for commercial re-use or in order to create a derivative work.
} 
the eighteenth-century philosophes themselves. ${ }^{2}$ According to this narrative, erudite history and antiquarianism, having matured in the sixteenth and early seventeenth centuries, came under heavy skeptical fire later in the century as part of the "crisis of the European mind."3 Although it managed to weather that crisis, erudite history emerged weakened and was eventually defeated and replaced by a new mode of historical enquiry: philosophical history, the newcomer, was more concerned with a bird's-eye view of the development of human institutions and practices throughout history than with the minutiae of Xenophon's Cyropaedia or the private life of a typical Roman citizen that occupied the érudits at the Académie des inscriptions.

This article contributes to the revision of this historical narrative that has picked up pace in the last decade. ${ }^{4}$ By means of a study of the dissertations published in the Histoire de l'Académie royale des inscriptions et belles lettres and the Mémoires de littérature tirez des registres de l'Académie royale des inscriptions et belles-lettres from 1710 to 1740 and of Hume's writings on the nature of historical evidence in the 1740s and early 1750s, it shows that David Hume and the académiciens were not as far apart as one might think. During the period analyzed here, the Académie was constantly concerned with the question of how to ground historical evidence in a solid philosophical and historical foundation. Building upon a shared seventeenth-century legacy-most notably John Locke's Essay Concerning Human Understanding (1689) and Pierre Nicole and Antoine Arnauld's Logique, ou l'art de penser (1662)-the académiciens argued that the certainty of a historical event could be attested if the historian showed that its causes were similar to those observed in common human experience. From this foundation, the Académie debated intensely over forms of organizing broad chains of historical causation: what was the role of comparison between societies or of sacred history, for instance? The académiciens regarded those concerns as what distinguished them from their sixteenth- and seventeenth-century erudite predecessors. Further, they developed a keen interest in topics that we usually associate with philosophical history-manners, the development of the arts and sciences, governmental policy-even if they did so from the perspective of an erudite historian, not of a philosophe.

Hume, starting his intellectual career immediately after this period, was aware of the debates in the Académie; indeed, as will be shown below, he likely drew from the work of some académiciens. He shared with them the notion that the

\footnotetext{
${ }^{2}$ Arnaldo Momigliano, "Ancient History and the Antiquarian," Journal of the Warburg and Courtauld Institutes 13/3-4 (1950), 285-315. See Blandine Kriegel, La défaite de l'érudition (Paris, 1988), for a more recent restatement of the thesis of the "defeat of erudition."

${ }^{3}$ As made famous by Paul Hazard, La crise de la conscience européenne (Paris, 1935).

${ }^{4}$ Dimitri Levitin is perhaps the historian who has done the most towards revising this thesis in the last decade, showing that seventeenth-century erudite scholarship and antiquarianism already contained many elements that are considered characteristic of the Enlightenment. Levitin's works are cited below. Although this paper partially agrees with Dimitri in emphasizing the importance of erudite history to the Enlightenment, it does so by claiming that erudite historians tried to change their practices, whereas Levitin would rather stress the continuities between seventeenth- and eighteenth-century historiography. See Anthony Ossa-Richardson, "Book Review. Ancient Wisdom in the Age of New Science: Histories of Philosophy in England, c.1640-1700," Erudition and the Republic of Letters 3 (2018), 83-96, for a more critical review of Levitin's work. Jacob Soll, 'Introduction: The Uses of Historical Evidence in Early Modern Europe', Journal of the History of Ideas 64 (2003), 149-57, also develops the connections between Enlightenment and seventeenth-century historical criticism.
} 
trustworthiness of a historical account was tied to its verisimilitude to common experience. But he went further to apply his experience-based science of human nature not only to what was reported but also to the witnesses themselves: witnesses and historians are human agents after all, and as such their behavior can also be understood in terms of the science of human nature. Hume also went further on the importance of causes: instead of using causal analysis to sustain a factual account as the académiciens did, he made causes (especially broad socioeconomic and political causes) the very object of history. By 1757, Hume discussed the origin of religious belief in his Natural History of Religion without even acknowledging the long erudite debates about the topic (with which he was acquainted).

Thus I suggest that philosophical and erudite history are closer than one might imagine. Rather than interpreting the transition into the Enlightenment as a moment of crisis and feebleness in erudite history-which eventually led to its "defeat" at the hands of philosophical history later in the century-I claim that the transition was a prise de conscience, rather than a crise: erudite history reformulated itself in the early eighteenth century according to the esprit philosophique that dominated the self-understanding of the Republic of Letters in this period. ${ }^{5}$ This reformulation opened space to a different approach to history, namely philosophical history, that eventually became almost self-sufficient from and sometimes even hostile-in public at least-to its older erudite relative.

To be sure, there have been attempts to show that there was some proximity between philosophical and erudite history. ${ }^{6}$ However, such attempts have mostly relied either on the more obvious cases of Montesquieu and Gibbon, who were to some extent involved in erudite debates, or on the mere use of erudite works for other purposes by notable philosophes such as d'Alembert or Voltaire. By juxtaposing Hume and the académiciens, the present study goes deeper into the very foundation of the different kinds of historical enquiry. Further, in picking up a rather forgotten and perhaps surprising connection between Hume and the académiciens, it shows that the connection between erudition and philosophical history was closer and stronger than has been suggested.

There have also been suggestions that some of the most notable académiciens such as La Curne de Sainte-Palaye or Nicolas Fréret should be considered Enlightenment thinkers as much as Voltaire or Montesquieu. ${ }^{7}$ However, these suggestions have so far relied exactly on the ability of those érudits to stand out from their milieu. But rather than taking erudite history to be a defeated discipline with some notable outliers-however true its loss of prestige in the eyes of eighteenthcentury public opinion may have been-I regard it as a historical practice

\footnotetext{
${ }^{5}$ Dan Edelstein, The Enlightenment: A Genealogy (Chicago, 2010), 13.

${ }^{6}$ See most notably Chantal Grell, L'histoire entre érudition et philosophie: Étude sur la connaissance historique à l'âge des Lumières (Paris, 1993), 20-33; and J. G. A. Pocock, Barbarism and Religion: The Enlightenments of Edward Gibbon (Cambridge, 1999), 137-68. For other attempts to revise this and other seminal contributions of Arnaldo Momigliano see Peter N. Miller, ed., Momigliano and Antiquarianism: Foundations of the Modern Cultural Sciences (Toronto, 2007).

${ }^{7}$ See Lionel Gossman, Medievalism and the ideologies of the Enlightenment: The World and the Work of La Curne de Sainte-Palaye (Baltimore, 1968), for the former; and Pocock, Barbarism and Religion, 155, 168, for the latter.
} 
undergoing changes that are important to our comprehension of other forms of historical practice more often associated with the Enlightenment.

In a broader perspective, this article contributes to the revision of the narrative of the Enlightenment that is ongoing beyond the confines of the history of historiography, changing our understanding of what brought about the Enlightenment. As suggested above, the article works towards an understanding of the early Enlightenment that emphasizes the transformations coming from within orthodoxy rather than giving exclusive attention to freethinker and skeptic outsiders as agents of intellectual change. It has already been argued that the supposed threat of naturalism was often conjured by believers themselves, ${ }^{8}$ and that the dialectic between skeptical doubts and answers to them was convergent rather than divergent. ${ }^{9}$ Recent literature has also shown that critical weapons employed by critics of religion were often of very orthodox provenance. ${ }^{10}$ As will be shown in what follows, insofar as the nature of historical evidence is concerned, the lines separating freethinkers and skeptics, on the one hand, and their more orthodox opponents, on the other, were blurry, sometimes barely perceptible.

Perhaps the Enlightenment was more of an inside job than we believed-what is presented here is but one example of that.

\section{Changes in seventeenth-century erudite history}

Before we move to Hume and the Académie des inscriptions, it is crucial to outline the seventeenth-century context out of which their practices developed. Two developments shaped the foundations of early eighteenth-century historical discourse, one internal to the discipline and one concerning its philosophical foundations.

On the internal side, the development of Renaissance humanist critical-historical methods into the early modern period often raised more questions than answers, exposing religious orthodoxies, Protestant and Catholic, to skeptical doubts generated within their own ranks. For instance, the development of the discipline of chronology led to puzzles that could not be solved within established orthodox boundaries, most notably with Joseph Scaliger's attempts to fit alternative chronologies within a biblical framework. ${ }^{11}$ The development of critical tools also created a tendency to historicize the Old Testament; that is, to treat it as a document composed by human hands rather than by divine inspiration, meaning it had a history to be studied. This was already common knowledge by the time Spinoza and

\footnotetext{
${ }^{8}$ See Alan Charles Kors, Naturalism and Unbelief in France, 1650-1729 (Cambridge, 2016), 269-88.

${ }^{9}$ See Anton M. Matytsin, The Specter of Skepticism in the Age of Enlightenment (Baltimore, 2016), 23362. See also Dario Perinetti, "Philosophical Reflection on History," in Knud Haakonssen, ed., Cambridge History of Eighteenth-Century Philosophy (Cambridge, 2005), 1107-40.

${ }^{10}$ On the religious origins of unorthodox critical "weapons" see esp. Noel Malcolm, Aspects of Hobbes (Oxford, 2002), 410-31. Ian Hunter, "Secularization: The Birth of a Modern Combat Concept," Modern Intellectual History 12/1 (2015), 1-32, Charly Coleman, "Resacralizing the World: The Fate of Secularization in Enlightenment Historiography," Journal of Modern History 82 (2010), 368-95; and Dmitri Levitin, "From Sacred History to the History of Religion: Paganism, Judaism, and Christianity in European Historiography from Reformation to Enlightenment," Historical Journal 55 (2012), 1117-60, also argue that "secularization" came mostly from within non-secular debates.

${ }^{11}$ Anthony T. Grafton, "Joseph Scaliger and Historical Chronology: The Rise and Fall of a Discipline," History and Theory 14 (1975), 156-85.
} 
Hobbes put the theory of non-Mosaic authorship of the Pentateuch to anticlerical use. ${ }^{12}$ By the beginning of the eighteenth century, the idea that treating the biblical text as a historical document strengthened rather than weakened its account was already firmly established. ${ }^{13}$ Outside religious matters, the problem of how to criticize and interpret ancient texts which simultaneously belonged to a distant past and were still used in contemporary law posed complex questions concerning the relation between past and present. ${ }^{14}$ Erudite historians expanded their critical apparatus, gaining access to new sources while discrediting others. ${ }^{15}$ At the turn of the century, the querelle des anciens et des modernes (and its English version, the Battle of the Books) transformed the way early modern Europeans approached their historical past, in terms of method as much as narrative, despite its ostensible emphasis on aesthetics. ${ }^{16}$ Even before that, erudite historians and antiquarians had already been engaging in what would become "cultural history" in the nineteenth century. ${ }^{17}$

On the philosophical side, the Cartesian demotion of history from knowledge to mere memory-that is, memories of past sensorial information, in contrast to demonstrative knowledge we arrive at by the exercise of our own reason-made philosophers search for a new epistemological foundation to non-demonstrative areas of human knowledge such as history. ${ }^{18}$ Pierre Nicole and Antoine Arnauld provided the most congenial answer to the Cartesian invective-it remained the starting point for the debate about historical evidence for a century-arguing that testimony could be securely grounded on moral certainty, a form of certainty more adequate to the subject than geometric certainty. ${ }^{19}$ Their apologetic take

\footnotetext{
${ }^{12}$ Malcolm, Aspects of Hobbes, 404-31.

${ }^{13}$ Grell, L'histoire entre érudition et philosophie, 53-6; Levitin, "From Sacred History to the History of Religion," 1123-7; J. G. A. Pocock, "Historiography and Enlightenment: A View of Their History," Modern Intellectual History 5/1 (2008), 83-96; and John Robertson, 'Sociability in Sacred Historical Perspective, 1650-1800', in Béla Kapossy, Isaac Nakhimovsky and Richard Whatmore, eds., Markets, Morals, Politics: Jealousy of Trade and the History of Political Thought (Cambridge, MA, 2018), 58-64.

${ }^{14}$ J. G. A. Pocock, The Ancient Constitution and the Feudal Law: A Study of English Historical Thought in the Seventeenth Century (Cambridge, 1987), 8.

${ }^{15}$ On the effects of the loss of credibility of Hellenistic sources in the seventeenth century see Dmitri Levitin, "Egyptology, The Limits of Antiquarianism, and the Origins of Conjectural History, c.16801740: New Sources and Perspectives," History of European Ideas 41 (2015), 703-71; see also Guy G. Stroumsa, A New Science: The Discovery of Religion in the Age of Reason (Cambridge, 2010), 39-48, 145-9, on the discoveries of Hebraic and Chinese sources on discussions about religion.

${ }^{16}$ On the French side of the querelle see Larry F. Norman, The Shock of the Ancient (Chicago, 2011), 1133. On the Battle of the Books see Joseph M. Levine, The Battle of the Books: History and Literature in the Augustan Age (Ithaca, 1991), esp. 267-84.

${ }^{17}$ See Peter Miller, "Introduction: Momigliano, Antiquarianism, and the Cultural Sciences," in Miller, Momigliano and Antiquarianism, 3-48; Ingo Herklotz, "Arnaldo Momigliano's 'Ancient History and the Antiquarian': A Critical Review," in ibid., 127-43; and Mark Phillips, "Reconsiderations on History and Antiquarianism: Arnaldo Momigliano and the Historiography of Eighteenth-Century Britain," Journal of the History of Ideas 57 (1996), 297-316.

${ }^{18}$ For Descartes see René Descartes, Descartes: Selected Philosophical Writings, trans. John Cottingham, Dugald Murdoch and Robert Stoothoff (Cambridge, 1988), 22-3, 29. Chantal Grell, Le dix-huitième siècle et l'antiquité en France, 1680-1789 (Oxford, 1995), 389-92, provides a useful summary of Cartesian takes on historical knowledge.

${ }^{19}$ Antoine Arnauld and Pierre Nicole, La logique, ou l'art de penser: Contenant, outre les regles communes, plusieurs observations nouvelles, propres à former le jugement. Quatrième édition, reveuë et augmentée
} 
emphasized the external circumstances of testimony; that is, investigation of the circumstances of the witness, rather than the internal circumstances of what she reported. This approach shifted the burden of proof to the skeptic, who had to argue that a particular testimony was invalid because of the witness's circumstances.

It backfired badly, though: skeptics like François de La Mothe Le Vayer and Pierre Bayle outflanked Arnauld and Nicole exactly in this spot. Bayle's Augustinian-Calvinist view of human nature applied to historians as well, who were as passionate, quarrelsome and prejudiced as any other human being (if not more so). ${ }^{20}$ Indeed, he famously argued that he "never reads Historians with a view to instruct himself in things past, but to know what is said by each nation and party about those things." 21 His Dictionnaire historique et critique portrays an endless parade of bitter scholarly quarrels that jeopardized the commitment of the Republic of Letters to truth (including historical truth). ${ }^{22}$ Before Bayle, La Mothe Le Vayer had argued that, besides the fact that we only get to know the winners' version of history, the historian is often between a rock and a hard place: if he is close enough to the event to be well informed, he will often be an interested party, but if he is distant enough to be disinterested, he exposes himself to the naivety or malice of firsthand witnesses. ${ }^{23}$ Their skepticism notwithstanding, both thinkers were themselves historians and thought history was valuable if external circumstances could be corrected: La Mothe Le Vayer advocated that historians write "memoirs" of their own times for posterity, while Bayle thought historians had to thoroughly criticize previous accounts, thus producing a residual truth out of the correction of previous errors. ${ }^{24}$ Indeed, Bayle argued, history could attain a higher degree of certainty than geometry if only historians adopted the correct methods. ${ }^{25}$

Locke sought to protect the apologetic aims of Arnauld and Nicole by throwing his weight on the opposite flank, the internal circumstances. Book Four of the Essay Concerning Human Understanding rested the foundation of belief in testimony on

(Paris, 1674), Part 4, chaps. 11-14. On the importance of the Logique to the seventeenth- and eighteenthcentury discussions of testimony see Ian Hacking, The Emergence of Probability: A Philosophical Study of Early Ideas about Probability, Induction and Statistical Inference (Cambridge, 2006), 73-84; and David Wootton, "Hume's 'Of Miracles': Probability and Irreligion," in M. A. Stewart, ed., Studies in the Philosophy of the Scottish Enlightenment (Oxford, 1990), 191-230, at 196-7.

${ }^{20}$ On Bayle's view of human nature as fallen and passion-driven see John Robertson, The Case for the Enlightenment: Scotland and Naples 1680-1760 (Cambridge, 2005), 216-25, 256-61. D. van Kley, "Pierre Nicole, Jansenism, and the Morality of Enlightened Self Interest," in Alan Charles Kors and Paul J. Korshin, eds., Anticipations of the Enlightenment in England, France, and Germany (Philadelphia, 1987), 69-85, shows how Nicole held moral views not dissimilar from Bayle's Augustinianism.

${ }^{21}$ Pierre Bayle, Critique generale de l'histoire du calvinisme de Mr. Maimbourg (Amsterdam, 1682), 16. All translations from French in this article are mine.

${ }^{22}$ On the Dictionnaire and the quarrels it portrays, including Bayle's own feuds with Pierre Jurieu, see Mara van der Lugt, Bayle, Jurieu, and the Dictionnaire Historique et Critique (Oxford, 2016), 15-116.

${ }^{23}$ François de La Mothe Le Vayer, "Du peu de certitude qu'il y a dans l'histoire," in Gérard Ferreyrolles, ed., Traités sur l'histoire: 1638-1677 (Paris, 2013), 215-50, at 237, 241.

${ }^{24}$ On Bayle's historical method see Ruth Whelan, The Anatomy of Superstition: A Study of the Historical Theory and Practice of Pierre Bayle (Oxford, 2013), 60-115; and Elisabeth Labrousse, 'La méthode critique chez Pierre Bayle et l'Histoire', Revue internationale de philosophie 11 (1957), 450-66.

${ }^{25}$ Pierre Bayle, Projet et fragmens d'un dictionaire critique (Rotterdam, 1692), Introduction, Section IX. 
the conformity of what is reported to common experience, as the "King of Siam" anecdote summarized: it is the king's experience that determines whether the Dutch ambassador's report is trustworthy or not. ${ }^{26}$ External circumstances came into play only when the proposition was indifferent to experience, as in the statement "a man named Julius Caesar was the Emperor of Rome about two thousand years ago." 27 However, historical facts, as this example highlights, mostly fall in a category to which experience is indifferent, and thus they "must stand or fall" by testimonies and their external circumstances as Arnauld and Nicole had argued. ${ }^{28}$ As such, the trustworthiness of history and reported miracles was liable to decline due to the decay of the quality of the chain of testimonies. In order to save miracles, Locke exempted them from his general framework: they had the testimony of God in their favor, even if Locke himself could not point to exactly what that meant. ${ }^{29}$

Although he emphasized the internal circumstances of (nonreligious) testimony, Locke did not extend his treatment to events more complex than "that fire warmed a man." ${ }^{30}$ But, as we shall see below, his revision of Arnauld and Nicole had an important impact: it opened the way for historical evidence to be assessed according to its verisimilitude to our own experience of causes in common life. Experience, it would be argued, is not indifferent to most historical events if we look at their causes: experience may be indifferent to the existence of a man named Caesar, but it was not indifferent to a statement about Caesar's actions, their motives and consequences. However, historians, if they chose to adhere to such a framework, still had to work out exactly what assessing evidence of complex historical events according to common experience meant: how should one judge historical institutions like the constitution of Sparta or figures such as the population of Rome-much more complex than fire's warmth-according to experience?

\section{The debates on the nature of historical evidence and the claim to Enlightenment in the Académie des inscriptions}

The Académie des inscriptions et belles-lettres was founded on 1663 by French finance minister Jean-Baptiste Colbert as the Académie royale des inscriptions et médailles to supervise the creation of medals and monuments in praise of Louis XIV. After its reform in 1701, the petite académie quickly became the center of erudition and scholarship in France and perhaps Europe. ${ }^{31}$ From 1717, the Académie regularly published volumes with a selection of dissertations read in its sessions either in full (the Memoires de littérature) or as summaries (the Histoire de

\footnotetext{
${ }^{26}$ John Locke, An Essay Concerning Human Understanding, ed. P. H. Nidditch (Oxford, 1975), 656-7. For the importance of this anecdote see Carlo Borghero, "Le roi du Siam et l'historien," Dix-huitième siècle 39 (2007), 23-38.

${ }^{27}$ Locke, An Essay Concerning Human Understanding, 662-3.

${ }^{28}$ Ibid., 664 .

${ }^{29}$ Ibid., 667-8.

${ }^{30}$ Ibid., 662.

${ }^{31}$ For an institutional history of the Académie see Blandine Barret-Kriegel, Les académies de l'histoire (Paris, 1988). Henri Duranton, "Le métier d'historien au XVIIIe siècle," Revue d'histoire moderne et contemporaine 23 (1976), 481-500, discusses its social composition.
} 
l'académie). ${ }^{32}$ The dissertations read between the 1710 s and the 1730 s reveal an attempt to reposition the work of the Académie in the institutional arrangement of the French academies and of the broader Republic of Letters centered around them. From its foundation to its reform in 1701, the Académie had a fairly limited role of giving historical consultancy to the French Crown on medals and inscriptions. After its reform, it was assigned a much broader scope of activities and it sought to redefine itself to be up to the task..$^{33}$

The académiciens sought to redefine themselves according to what they understood as the historian's version of the esprit philosophique. This philosophical spirit was perceived as the most important characteristic of contemporary intellectual activity in the self-understanding of French men and women of letters at the turn of the century. ${ }^{34}$ Pursuing erudite historical scholarship according to the philosophical spirit meant, above all, doing it differently from their humanist predecessors-Scaliger, Vossius, Pétau, Grotius, etc.-even if the académiciens openly acknowledged their debt to their predecessors. As the Abbé Gédoyn put it in 1736, it meant adding to the "universal man, prodigy of erudition," of the humanist era, the habit of the contemporary astronomer or chemist of "believing nothing but their eyes, their own experience," because they "had learned to doubt, and to be certain about the truth by means of a kind of incredulity." 35 A dozen years before, Fréret-speaking from across all the many political, religious and philosophical lines that divided the Académie as much as wider French intellectual life-had also said that it was principally in matters of method that eighteenth-century historians differed from their humanist predecessors. ${ }^{36}$

But what exactly did believing only in experience mean to a historian working with ancient sources? This was the question Louis-Jean Levesque de Pouilly posed to the Académie in 1722, when he launched an attack on the certainty of the history of the early Roman Republic. De Pouilly's skeptical invective against the early history of Rome provoked reactions by the Abbé Claude Sallier, professor of Hebrew at the Collège royal and later keeper of the royal library, and Fréret, in an exchange that lasted until $1725 .^{37}$ At the center of the debate was the question of what sources were available to later Roman thinkers like Livy or Cicero and what

\footnotetext{
${ }^{32}$ References to the dissertations (MAI) and summaries (HAI) are hereafter noted according to the editions printed by the Imprimerie royale in Paris: tome numbers are given before page numbers; the year in which the dissertation was read to the Académie is given in parentheses if available. For a detailed account of the publication and reprint of the dissertations of the Académie see Barret-Kriegel, Les académies de l'histoire, $205 \mathrm{n}$.

${ }^{33}$ On the "information system" developed by the French minister Jean-Baptiste Colbert, of which the Académie was part in its early years, see Jacob Soll, The Information Master: Jean-Baptiste Colbert's Secret State Intelligence System (Ann Arbor, 2009). The preface to the first volume of the memoirs (HAI 1) presents the new regulations under which the Académie operated after its reform and the themes and disciplines it would cover.

${ }^{34}$ See Edelstein, The Enlightenment, 24-30.

${ }^{35}$ Nicolas Gédoyn, "Si les anciens ont esté plus sçavants que les modernes, \& comment on peut apprécier le mérite des uns \& des autres," MAI 12.80-106, at 105 (1736).

${ }^{36}$ Nicolas Fréret, "Reflexions sur l'étude des anciennes histoires, \& sur le dégré de certitude de leurs preuves," MAI 6.146-89, at 147-8 (1724).

${ }^{37}$ The debate was published in MAI 6.14-189 (1722-25). Unfortunately, much of the attention given to the Académie in anglophone intellectual history is limited to this debate.
} 
use they made of them. De Pouilly argued that sources such as the annals of the pontifices, upon which later Roman historians relied, were ridden with fables and that they did not have access to much information from before the sack of Rome by Gallic tribes in c.390 BC anyway. ${ }^{38}$ Sallier answered that losses were partial and that public documents like those mentioned by de Pouilly could not contain blatantly false accounts. $^{39}$

However, the debate went well beyond erudite discussions of cross-referencing among classical sources, authorship of some of them or the survival of public records in the ancient period. It was clear to both sides that for modern historians to understand and write histories of early Rome-or any history, for that matterthey had to develop arguments about how to judge sparse evidence and how to connect pieces of evidence into a coherent historical account. Although standing on opposite sides of the Académie like Fréret and Gédoyn, de Pouilly and Sallier also reached a similar conclusion: experience was to be the judge, but it was not to judge individual facts such as Locke's "a man was warmed by the fire"; rather, experience was supposed to judge the connections that formed what the académiciens often referred to as the fond de l'histoire.

Even before the debate, Fréret had already claimed in 1717, echoing Bayle, that history required its own genre of certainty and that comparing it to the certainty of demonstrative, geometrical knowledge was bound to produce Pyrrhonism. ${ }^{40}$ During the debate, de Pouilly argued that we can assess the verisimilitude of a reported event by judging its causes: if we have experience of similar causes producing events similar to what was reported, we should believe it. In other words, Locke's King of Siam was wrong in his distrust of the Dutch ambassador: his tropical experience range would surely have informed him of liquids becoming solid in colder temperatures. ${ }^{41}$ Sallier also argued that in the "theatre of world history ... the principle of movement of all men is the same; and the springs are so similar, that one would be surprised if their movements were always different" 42 - a claim Hume would make in his Enquiry Concerning Human Understanding, as will be shown below. He also argued that the burden of proof lies on the skeptic: "we know the causes that are capable of producing the particular effects that make this history

\footnotetext{
${ }^{38}$ Louis-Jean Levesque de Pouilly, "Discours sur l'incertitude de l'histoire des quatre premiers siècles de Rome," MAI 6.14-29, at 18-20 (1722); and Levesque de Pouilly, "Nouveaux essais de critique sur la fidélité de l'histoire," MAI 6.71-114, at 108-10 (1724).

${ }^{39}$ Claude Sallier, "Discours sur les premiers monumens historiques des romains," MAI 30-51, at 30-32 (1723); Sallier, "Second discours sur la certitude de l'histoire des quatres premiers siècles de Rome ou reflexions générales sur un traité qui se trouve parmi les oeuvres morales de Plutarque, sous ce titre: Paralleles des faits grecs et romains," MAI 6.52-70, at 52; and Sallier, "Troisieme discours sur la certitude de l'histoire des quatre premiers siecles de Rome," MAI 6.115-35, at 121-8 (1725). Hendrik Erasmus, The Origins of Rome in Historiography from Petrarch to Perizonius (Assen, 1962), 67-85, discusses seventeenth-century skeptical arguments against the history of the early Roman Republic.

${ }^{40}$ Nicolas Fréret, "Reflexions sur les prodigies rapportez par les anciens," MAI 4.411-36, at 435 (1717), although he was careful to avoid the skeptical implications that early eighteenth-century thinkers drew from Bayle; see, for instance, his "Reflexions sur l'étude des ancienne histoires ...," MAI 6.158 (1724). Fréret made the same point in his contribution to the 1722-5 debate; see MAI 6.184-5 (1724), this time referring explicitly to Leibniz.

${ }^{41}$ De Pouilly, "Nouveaux essais ...," MAI 6.73 (1724).

${ }^{42}$ Sallier, "Second discours," MAI 6.54-5.
} 
[of Early Rome]"; it is the skeptic who has to prove those causes are improbable and "contrary to our own observations," he concluded, immediately referring to Fréret's 1717 dissertation. ${ }^{43}$ The emphasis on experience was present in the Académie as a whole: for instance, in a curious exchange in 1730 between Louis Jouard de La Nauze and Nicolas Mahudel about an admittedly insignificant event, the authors disputed whether the history of Hero and Leander was a myth based on whether it was possible to swim across the Hellespont every night as the story claimed Leander did. ${ }^{44}$ Both sides agreed that verisimilitude to common experience was the criterion that decided the matter and used this trifling discussion to accuse each other of historical Pyrrhonism or naive belief in myths.

But what was the object being judged according to common experience? Here, Fréret's contribution to the debate seems to capture well the prevailing direction of the Académie: what truly distinguished the method of eighteenth-century erudite historians from that of their humanist predecessors was the latter's inability to connect "the events of ancient history with that chain and connection [cette suite \& cette liaison] that is the mark of true history." 45 They failed to see that "it is not enough to determine the general degree of authority of writers whose fragments we employ; it is often necessary to interpret them and complement them with conjectures and hypotheses that draw their strength from their probability and their connection to the rest of history." 46 This procedure is clear in Fréret's treatment of Xenophon: in 1715 he had argued that Xenophon's geography is generally trustworthy if the historian takes the pain to sort out the details; in 1726, however, he discredited the same author's Cyropaedia as a historical source: it was a roman de vertu presenting Socrates' moral philosophy in a historical setting. ${ }^{47}$

Sallier seconded Fréret in his 1725 contribution to the debate on early Rome: "History," he argued, "is the collection of many facts linked together by the thread of narrative," and it is the thread that confers certainty on the individual facts, not the opposite. Indeed, adapting Fontenelle's comments on physics to his own historical purposes, Sallier insisted that "many separate truths, if they are in a sufficiently large number, vividly reveal their relations and mutual dependences to our mind," as if they naturally sought to reunite themselves after some kind of violence had separated them. ${ }^{48}$ Similarly, Étienne de Foncemagne urged the medievalist branch of the Académie to also focus on the totality of evidence: all pieces of evidence, like the stones of a building, though possessing individual strengths, "concur in preparing the general consequence that results from their chain." ${ }^{\prime 9}$ Even de Pouilly, the

\footnotetext{
${ }^{43}$ Sallier, "Troisieme discours," MAI 6.130 (1725). Sallier would later make some concessions to pyrrhonism, again following Fréret in claiming its utility only lasted insofar as it was kept within just boundaries; see his "Remarques critiques sur le traité de Plutarque, ПЕPI TrXH乏," MAI 10.338-46, at 342 (1732).

${ }^{44}$ Nicolas Mahudel, "Reflexions critiques sur l'histoire de Héro et de Léandre," HAI 7.74-8 (1730); and Louis Jouard de la Nauze, "Remarques sur l'histoire d'Hero et de Léandre," MAI 7.240-49 (1730).

${ }^{45}$ Fréret, "Reflexions sur l'étude des ancienne histoires," MAI 6.147 (1724).

${ }^{46}$ Ibid., 147-8, emphasis mine.

${ }^{47}$ Nicolas Fréret, "Observations sur la Cyropédie de Xénophon, principalement par rapport à la Géographie," MAI 4.588-612 (1715); and Fréret, "Observations sur la Cyropédie de Xénophon, seconde partie," MAI 7.427-87, at 448, 456 (1726).

${ }^{48}$ Claude Sallier, "Troisieme discours," MAI 6.133-4 (1725), emphasis mine, and 6.129 (1725).

${ }^{49}$ Étienne de Foncemagne, "Mémoire pour établir que le Royaume de France a esté successif-héréditaire dans la premiére Race," MAI 6.680-727, at 682 (1724).
} 
skeptic, was willing to concede that reliable historical propositions could be derived from fabulous sources if they were general, not particular: for instance, the widespread accounts of Amazons or female warriors prove that women likely fought alongside men in ancient Asia Minor, even if it remained impossible to give precise details. $^{50}$

The kind of historical critique in which the académiciens were involved was thus, in their own view, that of finding a true kernel or background of history which connected events by their causes. They often called this background the fond de l'histoire and regarded their job as removing the shroud of myth, falsehood or lost evidence around it-not letting some false particulars tarnish the background (fond), in Sallier's words, or "reject[ing] the marvelous circumstances while conserving the background [fond]," in Fréret's. ${ }^{51}$ This was what eighteenth-century critique according to the philosophical spirit meant, Fréret argued; it was inseparable from the new philosophy, from which it borrowed that willingness to doubt and to which it provided the materials for reflection. ${ }^{52}$

Thus there was a background of true history-the fond de l'histoire-to be recovered and its truthfulness had to be judged according to its verisimilitude to our common experience. But there was still the problem of how to interpret this fond; that is, a question about how to group facts into wider constructions within the boundaries of experience. It was here that battles were fought in the Académie: not so much about methods, but about what kind of interpretations were afforded by the epistemological consensus they agreed upon.

A prime example of this dispute is the debate over the history of pagan religions. Although the debate was by no means confined to the Académie, the latter was the center of one of the most influential positions in the early eighteenth century, namely Abbé Antoine Banier's euhemerism. As Banier explained, the method underlying his studies of ancient mythology sought to find the historical content buried under the layers of fable and myth. ${ }^{53}$ Fabulous gods and heroes thus reveal kings or princes and mythical creatures reveal established customs and practices. This method had become so important to the Académie that Banier submitted his plans for the Mythologie et les fables expliquées par l'histoire, whose first volume appeared in 1738, for official approval by the Académie before its publication. The Académie approved his method and insisted that it was the only one capable of revealing the fond de l'histoire of myths and fables. ${ }^{54}$ It was more vraysemblable than any of the competing methodologies-those that considered pagan myths

\footnotetext{
${ }^{50}$ De Pouilly, “Nouveaux Essais...," MAI 6.87, 6.95 (1724).

${ }^{51}$ Claude Sallier, "Discours," MAI 6.47 (1723); and Fréret, "Reflexions sur l'étude des ancienne histoires," MAI 6.169 (1724).

${ }^{52}$ Fréret, "Reflexions sur l'étude des ancienne histoires," 6.151-2.

${ }^{53}$ Antoine Banier, "Histoire de Bellerophon," MAI 7.69-82, at 69 (1729). "Euhemerism" is a form of interpretation of myths that considers mythological characters to be apotheosized rulers and heroes (contrasting with allegorical interpretations). See Frank Manuel, The Eighteenth Century Confronts the Gods (New York, 1967), 85-125, for a discussion of eighteenth-century euhemerism. On the wider debate see John Robertson and Sarah Mortimer, "Nature, Revelation, History: Intellectual Consequences of Religious Heterodoxy c.1600-1750," in Sarah Mortimer and John Robertson, eds., The Intellectual Consequences of Religious Heterodoxy, 1600-1750 (Leiden, 2012), 1-46; and Grell, Le dix-huitième siècle et l'antiquité en France, 882-900.

${ }^{54}$ [Claude Gros de Boze], "Réflexions sur la mythologie," HAI 12.9-19, at 10.
} 
to be corrupted sacred history, sponsored by "the sçavants of the previous and current century," or creations of Egyptian or Phoenician superstition. ${ }^{55}$ Although Banier and others had adopted elements of the "diffusionist" theory before, his euhemerism was in 1738 a separate approach. ${ }^{56}$

In a dynamic similar to that of the seventeenth century, the not-at-all orthodox Fréret found in the orthodoxy's adherence to euhemerism an opportunity to push for further historicization and naturalization of religion, including Christianity. $\mathrm{He}$ systematically called for a historical treatment of Scripture: on the one side, Fréret argued that the Old Testament, as a "monument of ancient history," had a strength that many other monuments lacked, namely the fact that some of its "historical books" were written close to the events they reported, and, more importantly, the care that had been taken by religious institutions to preserve its content. ${ }^{57}$ As such, it could and should be used as evidence of ancient history. On the other side, Fréret argued that sacred history, insofar as it is history, ought to be subject to the full scrutiny of historical critique. ${ }^{58}$ Again in his reaction to Banier's defense of Xenophon as a historical source, he rejected the attempts of Renaissance scholars to square profane history with the prophecies in the Book of Daniel: "One must explain the writings of the prophets by history, not the historians by the interpretations of the prophets we make; that seems to me one of the first rules of sacred [historical] critique." ${ }^{59}$ Claiming that the prophecies turned out true because they agreed with what is reported by Xenophon undermines them, given that even pagan authors themselves considered Xenophon's Cyropaedia a novel. ${ }^{60} \mathrm{He}$ concludes the dissertation by connecting those attempts to the esprit de systeme that reigned before the philosophical spirit appeared. ${ }^{61}$

Fréret also tried to push for a new approach in place of Banier's euhemerist understanding of pagan myth. To some extent, Fréret did accept Banier's method, employing it and acknowledging that his colleague had "a kind of exclusive right"

\footnotetext{
${ }^{55}$ Ibid., $12.15-18$.

${ }^{56}$ For Banier see Antoine Banier, "Dissertation sur l'origine du culte que les Egyptiens rendoient aux animaux," MAI 3.84-97 (1716). The Abbé Anselme argued that the "unknown God" of the Athenians was actually the Old Testament God (Abbé Anselme, "Dissertation sur le dieu inconnu des Atheniens," MAI 4.560-73 (1715)) and regarded pagan miracles as priestcraft (Abbé Anselme, "Dissertation sur ce que le paganisme a publié de merveilleux," MAI 4.399-410 (1717)); Henri Morin, "De l'usage de la prière pour les morts parmi les payens," HAI 3.84-9 (1711), also argued that the pagan custom of praying for the dead came from the Hebrews rather than the other way round. Pierre Bonamy, "Du rapport de la magie avec la théologie payenne," HAI 7.23-32 (1728), adopted the Phoenician/Egyptian ur-religion theory.

${ }^{57}$ Nicolas Fréret, "Essay sur l'histoire et la chronologie des assyriens de Ninive," MAI 5.331-404, at 344, 334 (1722-4). This same argument had been made by the Abbé Anselme in his "Des monumens qui ont supple au deffaut de l'écriture, \& servi de mémoires au premiers historiens," MAI 4.380-99, at 387 (1715).

${ }^{58}$ Fréret, "Observations sur la Cyropédie de Xénophon, seconde partie," 7.459.

${ }^{59}$ Ibid., 7.469. The prophecies of the Book of Daniel were used by Renaissance scholars-notably Protestants-to frame a universal history whereby the Holy Roman Empire would be the last empire before the Kingdom of God. Thus this is a point where compatibility between sacred and profane history had even more importance. Jean Bodin devoted a whole chapter of his Methodus ad facilem historiarium cognitionem (1566) to the refutation of this theory. See Anthony T. Grafton, What Was History? (Cambridge, 2007), 167-75. In rehearsing Bodin, Fréret is making a case for de-sacralization of history; that is, trying to disentangle it from a philosophy of history grounded on Revelation.

${ }^{60}$ Fréret, "Observations sur la Cyropédie de Xénophon, seconde partie," 7.460.

${ }^{61}$ Ibid., 7.478 .
} 
in mythological studies due to his efforts. ${ }^{62}$ However, Fréret imposed some limits to the usefulness of Banier's method: euhemerism could plausibly lead to the conclusion that some fabulous stories had an original historical kernel, but it could not point out precisely what was the kernel and what was the fable. Instead, Fréret advocated and practiced a comparative method. ${ }^{63}$ Already in the debate with Pouilly and Sallier, he observed that his sixteenth- and seventeenth-century predecessors lacked a comparative approach. ${ }^{64}$ In a 1747 dissertation on the religions of ancient Gaul and Germany, Fréret concluded-as Hume would a decade laterfrom his comparative studies that polytheism was always the first religion of human societies: "Since we found the same system [polytheism] in other barbarous nations that had no commerce among them, it must be a consequence of the first ideas that present themselves to men; and it is absolutely unnecessary to suppose that it has passed from one country to another." 65 To which he added, "it is very natural that the same needs and the same primitive ideas produce similar customs and that those produce similar opinions."

This, in turn, reveals a second example of the history according to the philosophical spirit practiced in the Académie that contributed to the interpretation of the fond de l'histoire: its interest in manners and opinions, another element that would become a staple of Enlightenment historiography. ${ }^{67}$ Fréret had long been pushing for more focus on manners and opinions: in a dissertation on the structure of Chinese writing, he argued that the "knowledge of the opinions of all peoples in the universe, is a domain of this academy as much as that of facts or languages." 68 But again, it would be wrong to see Fréret as an outlier in the Académie. In the very first volume of dissertations, the Académie designated the study of science, customs, laws, religion, games and even physical exercises of the

\footnotetext{
${ }^{62}$ Nicolas Fréret, “Observations sur le temps auquel a vécu Bellérophon," MAI 7.83-112, at 84 (1729).

${ }^{63}$ Nicolas Fréret, "Recherches sur l'ancienneté \& sur l'origine de l'art de l'equitation dans la Grece," MAI 7.286-335, at 320-21 (1730). Manuel, The Eighteenth Century Confronts the Gods, 108, argues that Fréret's method was still a form of euhemerism, but one that mapped myths onto a broad "cultural history," instead of considering them an account of the actual actions of rulers and heroes of the past. Although Fréret did consider some mythological characters as real persons, his attempts to collate from multiple sources a historical kernel that contained more generic statements about past societies perhaps deserve a different name, given that Fréret himself tried to impose some distance between him and Banier, especially in his later dissertations.

${ }^{64}$ Fréret, "Reflexions sur l'étude des ancienne histoires," 6.147.

${ }^{65}$ Nicolas Fréret, "Observations sur la religion des gaulois et sur celle des germains," MAI 24.389-431, at 395 (1747).

${ }^{66}$ Ibid., 24.419. On the importance of the question about the priority of polytheism and monotheism to Enlightenment social thought see Robertson, The Case for the Enlightenment, 217-25.

${ }^{67}$ Mark Phillips, Society and Sentiment: Genres of Historical Writing in Britain, 1740-1820 (Princeton, 2000), $160-87$.

${ }^{68}$ Nicolas Fréret, "Réflexions sur les principes généraux de l’art d'écrire, \& en particulier sur les fondements de l'écriture Chinoise," MAI 6.609-35, at 630 (1718). This dissertation deserves some special attention. As Pocock, Barbarism and Religion, 161-7, shows, Fréret's comparative study of non-European languages was one of the areas in which his comparative approach proved most fruitful. Also, following foonote 66, Fréret rehearses Bayle's argument that atheists could be moral agents "par des motifs de société" (ibid., 6.633). That his comparative study of Chinese writing (and the attendant knowledge of Chinese society) led him to this conclusion is certainly not without importance.
} 
many ancient peoples as one of its four objects of study. ${ }^{69}$ Examples abound throughout the thirty years analyzed here, ranging from the Abbé Jean-Baptiste Couture's remarkably detailed "De la vie privée des romains" to Henri Morin's broad historical surveys of poverty and celibacy, spanning from antiquity to the modern period. ${ }^{70}$ The académiciens could and did move from the minute details produced by their erudite enquiries to sweeping conclusions about the development of manners and customs: as the Abbé Augustin Nadal remarked in another minutely detailed account of the luxury of Roman women, dissertations on the "customs and usages" of nations can end up being a pile of disjointed facts but that was not the problem with his present subject, for "the source and progress of luxury are the same everywhere," to which he immediately added a general theory of the development of luxury and of its corrupting effects, supplemented with the necessary erudite details. ${ }^{71}$

Furthermore, the académiciens deemed their enquiries into the life of societies of the past, especially their technologies and their science, as fundamental to the success of current scientific endeavors: on the one side, science was an important aspect of the life of past societies, Nicolas Mahudel claimed in a dissertation about the lin incombustible (asbestos); on the other side, current science depended on the work of erudite historians to recover the scientific discoveries of the past and thus allow for new discoveries, as the role of erudite humanists in the Renaissance had shown, claimed De la Nauze. ${ }^{72}$ This exchange between science and belles lettres, de la Nauze added, was part of a wider exchange, embodied in the synergy among the French academies, in which the belles lettres contributed with both style and sources-without which "the history of the human spirit would remain buried in deep obscurity and the veil that hides the sciences would become impenetrable" - and the sciences contributed with "that philosophical spirit, without which erudition is chaos and discourse becomes a vain display of frivolous words."73

In conclusion, by the 1730s the académiciens had been developing for some twenty years a form of historical practice that was in many aspects closer to what we now consider Enlightenment historiography than to humanist scholarship. It was concerned with manners and opinions as philosophical historians would be later in the eighteenth century; it pushed-even among the more orthodox types, if to a lesser degree-towards the naturalization and historicization of religious belief; it used comparative approaches; and, above all, it did so based on an epistemology that, first, recognized a fond de l'histoire that made the causes of events a key

\footnotetext{
${ }^{69}$ HAI 1, préface. The other three were critical and grammatical dissertations, the description and explanation of monuments and the history of French Middle Ages.

${ }^{70}$ Jean-Baptiste Couture, "De la vie privée des romains, c'est-à-dire: ce qu'un particulier, menant une vie commune, fasoit dans le cours d'une journée; les heures ajustées à notre manière de compter," MAI 1.30151; Henri Morin, "Histoire critique de la pauvreté," MAI 4.296-307 (1717); and Morin, "Histoire critique du célibat,” MAI 4.308-25 (1713).

${ }^{71}$ Augustin Nadal, "Du luxe des dames romaines," MAI 4.227-63 (1712, 1714).

${ }^{72}$ Nicolas Mahudel, "Du lin incombustible," MAI 4.634-47 (1715); and Louis Jouard de la Nauze, "Des rapports que les belles-lettres \& les sciences ont entr'elles," MAI 13.377-8 (1735).

${ }^{73}$ De la Nauze, “Des rapports que les belles-lettres \& les sciences ont entr'elles," MAI 13.372-84, at 377-8 (1735).
} 
element of historical explanation and, second, judged interpretations of this fond according to experience. As de la Nauze summarized in 1736,

There where the historian seems to be only listing facts, the reader must make a thousand discoveries: there he must learn the order of times and places, without any chronological or geographical discussion; there he must uncover the principles of affairs, the motives, the intrigues, the most concealed springs; there he must distinguish good and evil, seemingly without any instruction; there he must discover the human heart and spirit, when we talk only of operations of the senses; there he must know, in short, men in depth, beneath the surface of their actions. ${ }^{74}$

\section{David Hume on historical evidence}

Hume probably met de Pouilly in Rheims on his way to La Flèche in France, where he drafted his Treatise of Human Nature (1739-40). ${ }^{75}$ At La Flèche he had the dissertations of the Académie des inscriptions at his disposal in the library of the Jesuit college, though there is no explicit biographical evidence that he ever read them there (or anywhere else, for that matter). ${ }^{76}$ His texts, however, suggest otherwise. A footnote in the essay "Of the Balance of Power" that has so far passed almost totally unnoticed is the key to uncovering this connection. ${ }^{77}$ Almost completely unrelated to the essay, we find in that footnote a reference to the debates concerning the certainty of the early history of Rome, an acknowledgment that the skeptic side was "not without reason," but seemed "scarcely defensible in its entirety," for "the revolutions seem so well proportion'd to their causes," and Machiavelli wrote "a comment on Livy (a work surely of great judgment and genius) founded entirely on this period, which is represented as fabulous." Surely ancient authors exaggerated their numbers, but this should not lead us to reject them completely, he concluded. ${ }^{78}$ Here we find in a nutshell Hume's take on the nature of historical evidence and we also find that his concerns in this area were very similar to those of the académiciens. ${ }^{79}$ There was, however, a decade-long path to this footnote.

Hume's Treatise of Human Nature dealt with historical evidence in two installments. First, in the section on "unphilosophical probability," Hume addresses the issue of the declining force of the chain of testimonies that sustains historical knowledge. Historical evidence depends on a chain of causes and effects that

\footnotetext{
${ }^{74}$ Louis Jouard de la Nauze, "De l'abus qu'on fait quelquefois d'une prétendue clarté de stile, en traitant les matiéres de littérature ou de science," MAI 13.384-99, at 398 (1736).

${ }^{75}$ Fernand Baldensperger, "La première relation intellectuelle de David Hume en France: Une conjecture," Modern Language Notes 57 (1942), 268-71.

${ }^{76}$ On Hume's period at La Flèche see Dario Perinetti, "Hume at La Flèche: Skepticism and the French Connection," Journal of the History of Philosophy 56 (2018), 45-74.

${ }^{77}$ Moritz Baumstark, "David Hume: The Making of a Philosophical Historian. A Reconsideration" (unpublished Ph.D. thesis, University of Edinburgh, Edinburgh, 2008), 88, being the only exception.

${ }^{78}$ David Hume, Essays: Moral, Political and Literary (Indianapolis, 1985), 633-4.

${ }^{79}$ Wootton, "Hume's 'Of Miracles'," argues that Hume's discussion of testimony in the Enquiry Concerning Human Understanding, which is presented below, was most likely taken from Fréret's contribution to the debate on historical pyrrhonism in the Académie. However, he does not draw any implications from this.
} 
goes back from the book we read to previous copies, other books and reports, until it reaches the eyewitness. Hume argued in a Lockean vein that, since the vivacity of belief declines with the length of the chain, this meant that "the evidence of all antient history must be now lost" and that any historical evidence will eventually lose its sway upon human minds. ${ }^{80}$ However, if we assume the fidelity of copyists and printers, most of the links in that chain are similar to each other and, "after we know one, we know all of them." 81 "This circumstance alone preserves the evidence of history," because it assures us that our knowledge of the past does not necessarily fade with time, as Locke had suggested. ${ }^{82}$

Still, the shortening of the chain of testimonies assumes the fidelity of writers, copyists and printers. Book II of the Treatise tackles the issue of testimony as a way to advance Hume's thesis concerning the doctrines of liberty and necessity. When we read of historical characters like Caesar or Nero, we remember that many other people have also affirmed their existence and think that they could not have all conspired together to deceive us, that their attempts to do so would have exposed them to the criticism of the public. The "moral evidence" that supports those conclusions, Hume argues, "is nothing but a conclusion concerning the actions of men, deriv'd from the considerations of their motives, temper and situation. ${ }^{\prime 83}$ In other words, we believe in a person's testimony in the same way we believe that someone will fulfil a contract: because we know that their passions give them no motive to do otherwise; that is, because giving false accounts of events exposes the person to public reproach, especially when the reported event is recent and other witnesses are still alive. He further argues that moral evidence is on the same footing as natural evidence; both kinds of evidence are based on the constant conjunction of objects - in the case of testimony, a certain set of circumstances such as publicity and the action of telling the truth. ${ }^{84}$

Thus the Treatise acknowledges that skeptics have a point against belief in historical testimony: belief must be suspended if the chain of testimony is not made of similar transmission links or if the science of human nature suggests that one of the transmission links cannot be trusted. Notwithstanding this possibility, the Treatise upholds our general confidence in history: "all our belief in history" is not at all different from the operations of the mind that involve other matters of fact, Hume argued in the Abstract, and despite the skeptics' victory in the more "abstruse" corner of philosophy, that victory does not affect our common-life belief in causal relations, historical writing and reading included. ${ }^{85}$ Indeed, Hume claimed that the mere fact of being told that a narration is a history rather than a novel makes us conceive the events in a livelier fashion: if a person reads a book as a romance and another reads the same book as a true history, thus

\footnotetext{
${ }^{80}$ David Hume, A Treatise of Human Nature, ed. David Fate Norton and Mary Norton (Oxford, 2007), Book 1, Part 3, Section 13, para. 4. On the importance of Locke's account belief in testimony to Hume see, for instance, Mark Boespflug, 'Locke on Testimony', British Journal for the History of Philosophy 27 (2019), $1135-50$.

${ }^{81}$ Hume, Treatise 1.3.13.6.

${ }^{82}$ Ibid., 1.3.13.6.

${ }^{83}$ Ibid., 2.3.1.15

${ }^{84}$ Ibid., 2.3.1.17.

${ }^{85}$ Ibid., Abstract, $\$ 10$, and 1.4.7.
} 
receiving "the same ideas, and in the same order," the latter will have "a more lively conception of all the incidents. He enters deeper into the concern of the persons ... while the former, who gives no credit to the testimony of the author, has a more faint conception of all these particulars." 86

The Enquiry Concerning Human Understanding applied Hume's reasonings in the Treatise to an actual case, the testimony of miracles. ${ }^{87}$ However, as we will see, his attempt to deny credibility to the testimony of miracles also put historical knowledge perilously close to skeptical doubts and he rushed to save it from such a fate.

Perhaps the most commented section of the first Enquiry concerning historical issues is the infamous paragraphs on the constancy of human nature in history. But instead of reading Hume as asking what history can do for the science of human nature (and concluding that it cannot do much), we might as well ask what the science of human nature can do for history. ${ }^{88}$ If "mankind is so much the same, in all times and places, that history informs us of nothing new or strange in this particular," being only "a collection of experiments, by which the politician or moral philosopher fixes the principles of his science," exposing forgery in historical accounts is the same as showing that "the actions, ascribed to any person, are directly contrary to the course of nature, and that no human motives, in such circumstances, could ever induce him to such a conduct." ${ }^{\prime 89}$ The science of human nature affords us a criterion to reject historical falsehood. It also affords an inclination to believe in testimony in general: "were not the memory tenacious to a certain degree; had not men commonly an inclination to truth and a principle of probity; were they not sensible to shame, when detected in a falsehood: Were not these, I say, discovered by experience to be qualities, inherent in human nature, we should never repose the least confidence in human testimony." 90

Testimony of miracles, however, does not work as testimonies in general. On the side of the events, Hume plainly rejects miracles as violations of the laws of nature and "as a firm and unalterable experience has established these laws, the proof against a miracle ... is as entire as any argument from experience can possibly be imagined." ${ }^{\prime 11}$ Hume spends more time discussing the problems of testimony of miraculous events, presenting four arguments against them: first, testimony of miracles usually does not possess the circumstances of a trustworthy report such as reporting something public that happened in a "celebrated part of the world" and was attested by persons of learning and reputation who would lose a great deal if falsehood was detected. Second, "surprize and wonder" please the human

\footnotetext{
${ }^{86}$ Ibid., 1.3.7.8.

${ }^{87}$ The section on miracles was likely written for the Treatise, but Hume removed it fearing the public's reaction. See Hume's letter to Rev. George Campbell in The Letters of David Hume, ed. J. Y. T Greig, 2 vols. (Oxford, 1932), 1: 360-61. Hume sent a first draft to Henry Home in 1737; see Letters, 1: 23-5.

${ }^{88}$ For an interesting take on Hume's views on the constancy of human nature see Spencer K. Wertz, Between Hume's Philosophy and History: Historical Theory and Practice (Lanham, 2000), 19-34. Duncan Forbes, Hume's Philosophical Politics (Cambridge, 1975), 102-21, remains the canonical position.

${ }^{89}$ David Hume, Enquiry Concerning Human Understanding, ed. Tom Beauchamp (Oxford, 2000), Section 8 , paras. 7,8 .

${ }^{90}$ Ibid., 10.5, original emphasis.

${ }^{91}$ Ibid., 10.12 .
} 
mind and make people inclined to believe and share testimonies of such unusual events; when mixed with the "spirit of religion" they are "an end of common sense; and human testimony, in these circumstances, loses all pretention to authority." Third, miraculous and supernatural events seem to occur mostly among "ignorant and barbarous nations": all the "first histories" of nations, written before any consistent development of learning, are full of such events and they tend to "grow thinner every page as we advance nearer the enlightened ages." Finally, each religion stands as contrary evidence to the miracles of others, even if they do not directly question the particular miracles upon which their counterparts rely. ${ }^{92}$ Besides those arguments, Hume adds that "the wise lend very academic faith" to reports (miraculous or otherwise) that favor the reporter's own faction. ${ }^{93}$ Therefore, belief in miracles requires that the falsehood of the testimony be more miraculous than the miracle itself, which means that we must "form a resolution, never to lend any attention to it, whatever specious pretence it may be covered [with]." 94

But how does history in general fare in relation to those criteria? As we have seen from the study of the wider debate on historical knowledge and historical evidence, many of the attacks Hume directs towards testimony of miracles were leveled against ancient pagan and even modern history. Thus much of what was accepted in the eighteenth century as trustworthy historical testimony lacked the required degree of publicity, did not happen in a celebrated part of the world, and was not attested by witnesses of reputation and credit who did not have particular interests related to the event. It could also be argued that "surprize and wonder," though perhaps not reaching the pitch of religious events, have their place in secular history. Indeed, Hume himself acknowledges that ancient historical sources were plagued by supernatural and miraculous events. ${ }^{95}$

Hume came to the rescue of history with a thought experiment: if he were told that there was "total darkness over the whole earth for eight days" in 1600, that would be a phenomenon worthy of investigation, but if he were told that Queen Elizabeth had been resurrected in that same year and it was "assigned to any new system of religion ... that very circumstance would be a full proof of a cheat." In other words, the very fact that a religious character was attributed to an unlikely event stamps on it the label of falsehood. In the end, therefore, what distinguishes testimony of miracles from historical testimony, insofar as external circumstances are concerned, is the fact that priests are not historians (nor are they common people, for that matter). That is, Hume's social theory of religion and priestcraft, put forward in essays such as "Of Superstition and Enthusiasm," "Of National Characters" ${ }^{\prime \prime 7}$ and the Natural History of Religion allows him to save historical testimony from the fate of religious testimony: unlike priests and those dominated by superstition and enthusiasm, historians cannot automatically be assumed to be lying.

\footnotetext{
${ }^{92}$ Ibid., $10.15-29$.

${ }^{93}$ Ibid., 10.29 .

${ }^{94}$ Ibid., 10.38 .

${ }^{95}$ Ibid., 10.25 .

${ }^{96}$ Ibid., $10.36-8$, italics mine.

${ }^{97}$ See specifically Hume, Essays, 199, n. 3.
} 
Thus the first Enquiry opens the possibility of questioning historical evidence in general in a deep sense and it leaves the access to such questioning in the hands of the science of human nature: Hume's science establishes, on the one hand, whether an event is contrary to common experience and, on the other hand, whether those who report that event deserve our trust. In the case of miracles, it connects the improbability of the miracle to the probability that those who spread and believe in it are either lying or being naive. If some recent commentators claim that "Of Miracles" was not very innovative in terms of the eighteenth-century debates on miracles per se, Hume's attempt to save history from the fate of miracles shows that his innovation lies instead in extending the framework beyond the debate about religion. ${ }^{98}$

Indeed, that is exactly what Hume does in "Of Commerce," the opening essay of the Political Discourses (1752), where he discusses how to deal with a historical account that, though not being strictly against the laws of nature, seems to defy our most basic experience of life in society. There, Hume makes a curious remark about Sparta: given the "peculiarity" of the laws by which that republic was governed, we justly esteem it a "prodigy"; indeed "were the testimony of history less positive and circumstantial, such a government would appear a mere philosophical whim or fiction." 99 Philosophical whim or fiction is the status of Plato's ideal republic and Hobbes's state of nature in Hume's view: the probability that a society based on those philosophers' accounts of human nature existed or could exist in the future is extremely low. Thus we reason justly in considering Plato's and Hobbes's accounts as mere fantasies or at best empty wishes. ${ }^{100}$ Sparta's constitution, by itself, would have followed the same destiny were it not for the strong testimonies proving its existence.

If the strength of testimonies did not allow Hume to reject the existence of Sparta and other ancient agrarian commonwealths, he believed that perhaps classical sources were overestimating their greatness. Indeed, we can read the Political Discourses as a sustained downplaying of the success of classical institutions when compared to their modern successors. Nowhere is this intention clearer than in the essay "Of the Populousness of the Ancient Nations," the closest to a work of erudition in the Humean corpus. It takes the position of the skeptic, as Hume himself admits, seeking to undermine the argument that European population was greater in ancient than in modern times, defended by Robert Wallace, Montesquieu and Vossius. ${ }^{101}$ By undermining the claim that population was larger in ancient than in modern times, Hume continued the assault on the reputation of classical institutions he had begun in the other essays of the Political Discourses since population size "commonly determines concerning the preference of their whole police, their manners, and the constitution of their government." ${ }^{\prime 102}$

\footnotetext{
${ }^{98}$ John Earman, Hume's Abject Failure: The Argument Against Miracles (Oxford, 2000), argues that "Of Miracles" was not innovative at all. Wootton, "Hume's 'Of Miracles'," 227-8, argues that "Of Miracles" is a general framework to deal with testimony rather than a solution to the specific case of miracles.

${ }^{99}$ Hume, Essays, 259.

${ }^{100}$ See Hume, Treatise, 2.3.1.10; and David Hume, Enquiry Concerning the Principles of Morals, ed. Tom Beauchamp (Oxford, 1998), Section 3, para. 15 n. 11.

${ }^{101}$ On Hume's concession that he is playing the skeptic see Hume, Essays, 639.

${ }^{102}$ Ibid., 381. For the importance of population in moral and political debates in the eighteenth century see Sylvana Tomaselli, "Moral Philosophy and Population Questions in Eighteenth Century Europe," Population and Development Review 14 (1988), 7-29. See M. A. Box and Michael Silverthorne, "The
} 
Hume divides "Of Populousness" into two parts, an "enquiry concerning causes" and another concerning "facts": the first is meant to discuss "whether it be probable, from what we know of the situation of society in both periods, that antiquity must have been more populous," and the second "whether in reality it was so."103 The first part continues in the same fashion as the other essays, anatomizing public and domestic economic, social and political institutions and practices of ancient societies with the purpose of showing that, contrary to the popular view in Hume's time, they were inhumane in a large part of their manners, mired in factious and violent political disputes and stuck in a backward and agrarian economic structure. Hence it was very unlikely that ancient societies were able to support a large population. These are answers to key arguments of the opposite view in the population debate: that ancient Roman and Greek slavery favored the reproduction of slaves by, among other things, affording them more humane treatment, and that republican governments based on a class of equal freeholders produced better economic and political outcomes, including population growth.

From the outset, Hume makes it clear that the enquiry concerning facts is covering very uncertain terrain: no one could be sure of population size in his own time and there was even less ground to discuss the population of ancient societies. ${ }^{104} \mathrm{Not}$ only was evidence limited, but even what was available might have been compromised: numbers are more easily corrupted than words because a single altered word makes the whole sentence unintelligible, alerting the reader to a possible corruption, while a missing digit often passes unnoticed. ${ }^{105}$ In this spirit, Hume limits the enquiry concerning facts to "real history," that which "philosophers" ought to be concerned with and which begins with the first page of Thucydides. ${ }^{106}$ Thus he excludes Nineveh, Babylon and Egyptian Thebes and turns to Rome and Greece, "to the sphere of real history," to calculate the population of cities. ${ }^{107}$ This exclusion is quite notable, as will be discussed in the final section below, because it simultaneously shows, on the one hand, that Hume shared with the académiciens a similar methodological answer to the question whether it was possible to write history as evidence becomes critically rarefied, and, on the other hand, that from this shared basis Hume (and other philosophical historians) would take a diverging path.

Hume goes on to further suggest (though he does not substantiate) that "in general, there is more candor and sincerity in ancient historians, but less exactness and care than in the moderns," or, in other words, that ancient historians often made correct claims, but based them on inflated figures, while their modern counterparts have correct figures, but infer wrong claims from them. ${ }^{108}$ Indeed, the main purpose of the essay is not to reject the accounts of ancient historians in broad

\footnotetext{
'Most Curious \& Important of All Questions of Erudition': Hume's Assessment of the Populousness of Ancient Nations," in Mark Spencer, ed., David Hume: Historical Thinker, Historical Writer (2013), $225-249$, at $225-7$, for a more recent restatement of this point.

${ }^{103}$ Hume, Essays, 381.

${ }^{104}$ Ibid., 381.

${ }^{105}$ Ibid., 421.

${ }^{106}$ Ibid., 422.

${ }^{107}$ Ibid., 437.

${ }^{108}$ Ibid., 422 n. 123.
} 
terms, but rather to deflate them in order to reject or at least throw some doubt upon modern opinions of classical institutions.

Hence, despite some reservations about ancient history, Hume does not take the route of generalizing the uncertainty of figures into an overall distrust of historical sources. Rather, he dives into a careful discussion of the figures given in classical sources. But how does Hume proceed in his exercise in criticism? Hume opens his enquiry concerning facts by defending modern criticism, in a paragraph that he removed in the 1760 edition:

The critical art may very justly be suspected of temerity, when it pretends to correct or dispute the plain testimony of ancient historians by any probable or analogical reasonings: Yet the licence of authors upon all subjects, particularly with regard to numbers, is so great, that we ought still to retain a kind of doubt or reserve, whenever the facts advanced depart in the least from the common bounds of nature and experience. ${ }^{109}$

That is, despite acknowledging that the enquiry concerning causes has to yield to the facts, that reasonings about causes are "mere trifling, or, at least, small skirmishes and frivolous reencounters, which decide nothing," the uncertainty of the facts leaves the field open to Hume's arguments concerning institutions and their natural, political, social and economic causes. ${ }^{110}$ The enquiry concerning facts thus presents the reader with a combination of the usual tools of erudition -cross-referencing of classical authors, analogical reasoning, comparison of figures, organization of missing information-with the kind of probabilistic causal reasoning that defines Hume's science of human nature. For instance, the absence of any rebellion of slaves in the accounts of the classical historians of Greece is considered as an argument against the inflated population of slaves attributed to that country: if the proportion of slaves to freemen were really twenty to one as reported by classical sources, some disturbance would probably have happened and the supposed gentle treatment of slaves would have been impossible, for, as modern American colonies showed, a much more rigorous treatment was necessary to keep black slaves under control. ${ }^{111}$ In another creative use of causal analysis, Hume takes the ancients' reports on the climate in Europe-which described the continent as much colder than in modern times-to be an indication that there were more woods and, consequently, fewer cultivated fields, thus implying that a population as large as that of his modern era could not be fed by ancient agriculture. $^{112}$

\footnotetext{
${ }^{109}$ Ibid., 641. Hume's take on the value of historical criticism here is very similar to that of William Wotton, a staunch defender of modern learning-which included modern historical critique of ancient historical sources-in the Battle of the Books, the English version of the querelle des anciens et modernes, as Baumstark notices (see Baumstark, "David Hume," 85-90). For Wotton's defense of modern historical critique see William Wotton, Reflections upon ancient and modern learning: to which is now added a defense thereof, in answer to the objections of Sir W. Temple, and others; with observations upon the Tale of a tub (London, 1705), 353-4.

${ }^{110}$ Hume, Essays, 421.

${ }^{111}$ Ibid., 429.

${ }^{112}$ Ibid., 449-51.
} 
In conclusion, although Hume tried to divide "Of Populousness" into two separate parts, his choice of verb to describe the essay is very appropriate: "I shall intermingle the enquiry concerning causes with that concerning facts." "I13 The two enquiries cannot be separated so easily, for facts are but points connected by relations of cause and effect. However, the causes Hume was interested in are not plain statements such as Locke's "a man is warmed by the fire." Quite the opposite, they are complex reasonings about the social, economic and political institutions of ancient societies. Thus even the "enquiry concerning facts" of "Of Populousness" must be read not only as a showcase of the erudition of Hume's readings in the $1740 \mathrm{~s},{ }^{114}$ but also as continuation of the kind of argument developed in the other essays of the Political Discourses and, in some form, of the science of human nature with which he had been engaged since the Treatise. It shows that historical evidence needs to be embedded in an account of human nature and its development in historical time. However, this account depended, in turn, on the very evidence it scrutinized.

\section{Convergences and divergences between philosophical and erudite history}

The convergences and divergences between Hume and the académiciens can be best summarized by Hume's footnote on the controversy about the early history of Rome. As mentioned above, the footnote acknowledges the debate about the nature of historical evidence and the doubts-"not without reason" - that could be raised about the early history of Rome. But the fact that Machiavelli could draw such solid political maxims from Livy lent credibility to the latter as a source, despite the other obvious problems his works presented as such. That is, our broader experience of politics confirms Machiavelli's theories, which in turn suggests that his source depicts plausible human interactions. The credibility of Livy as source is derived from that of Machiavelli as a theorist, not the other way round. In contrast, de Pouilly argued for the exact opposite: "the majority [of the accounts of the origins of Rome] are not sufficiently certain to be useful, and the philosophers who, like Machiavelli in his Discourse on the first decade of Titus Livius, ground their physical, moral or political observations upon them, do so on very fragile grounds." ${ }^{115}$

Thus Hume was willing to put causes above facts, to enquire about causes first and use them to ask questions about the facts, as the very ordering of the enquiries of "Of Populousness" suggests. ${ }^{116}$ We have seen that the académiciens-even de

\footnotetext{
${ }^{113}$ Ibid., 381, underlining mine, italics original.

${ }^{114}$ See Moritz Baumstark, "Hume's Reading of the Classics at Ninewells," Journal of Scottish Philosophy 8 (2010), 63-77. Box and Silverthorne, "The 'Most Curious \& Important of All Questions of Erudition'," also discuss Hume's use of ancient and modern sources in "Of Populousness." Although Hume was by no means an "erudite historian" he possessed a considerable familiarity with erudite scholarship. Against the argument that Hume merely copied other modern accounts see Roger I. Emerson and Mark G. Spencer, "A Bibliography for Hume's History of England: A Preliminary View," Hume Studies 40 (2014), 53-71. Those references combined should give a picture of how Hume spent considerable time becoming acquainted with erudite scholarship at least from the 1740s.

${ }^{115}$ De Pouilly, "Discours sur l'incertitude," MAI $6.14 \mathrm{n}$. A.

${ }^{116}$ To the surprise of even its best commentators, who deemed the choice "backward." See Box and Silverthorne, “The 'Most Curious \& Important of All Questions of Erudition'," 245.
} 
Pouilly, when he was not insisting on a skeptic point he himself seemed not to take very seriously-had been threading a similar path before Hume: they had recognized that bare facts made no history, that the fond de l'histoire had to be articulated in terms of causes, which were then judged according to their verisimilitude to common experience. Indeed, we have seen that this was the basis of their claim to share the "philosophical spirit" of their time and absent in their predecessors'.

But from this shared foundation, Hume took a different path. On the one hand, the académiciens continued to work within the "citadel of erudition," as Pocock put it. ${ }^{117}$ The place from which they spoke - and all that came with it: their educational background, the purposes of their enquiries-delimited how far they would go into the realm of causes: though causes could be used to support their factual claims, the académiciens were not in the business of proposing a causal analysis of historical developments. In a surprising twist, perhaps the best description of what the académiciens were doing in the early eighteenth century is Dugald Stewart's understanding of what, in his view, his fellow Scottish philosophers were doing: using conjectures about what might have happened to fill the gaps, to plug the events offered by sources into the fond de l'histoire. ${ }^{118}$ Fréret, one of the more philosophically inclined among the académiciens, had realized that the fond de l'histoire could become the object of a discipline by itself.

On the other hand, as we have seen, Hume limited his foray into erudition in "Of Populousness" to "real history"; that is, to historical writing after Thucydides. When Hume did discuss matters pertaining to very early human history, such as in his Natural History of Religion, he did so in a "wilfully unscholarly" manner: he knew the erudite scholarship on the matter, but decided that the natural history of religion could be explored more productively in a different way. ${ }^{119}$ Causes, Hume believed, could be dealt with perhaps more independently. Despite his studies of the Classics and his considerable knowledge of erudite work - which he made sure not to quote in the History of England, to the dismay of Horace Walpole-Hume sometimes thought it was better not to dive into erudite debate. ${ }^{120}$ Indeed, this sentiment seems to have grown from the 1750s onwards: besides the Natural History of Religion, he opened his account of the Roman conquest in his History of England scolding those "ingenious men" who spent too much time trying to push historical knowledge into the period preceding written sources: the only certain way of doing so was rather "to consider the language, manners, and customs" of those periods in a comparative fashion. ${ }^{121} \mathrm{He}$ also removed

\footnotetext{
${ }^{117}$ Pocock, Barbarism and Religion, 168.

${ }^{118}$ Dugald Stewart, "An Account of the Life and Writings of Adam Smith, L.L.D.," in W. P. D. Wightman, J. C. Bryce and Ian Simpson Ross, eds., Essays on Philosophical Subjects (Oxford, 1980), 269-332, at 292-4. This paper implicitly follows Emerson's understanding of Scottish conjectural history; see Roger L. Emerson, “Conjectural History and Scottish Philosophers," Historical Papers 19 (1984), 63-90.

${ }^{119}$ Richard Serjeantson, "David Hume's Natural History of Religion (1757) and the End of Modern Eusebianism," in Mortimer and Robertson, The Intellectual Consequences of Religious Heterodoxy, 26785 , at 281 .

${ }^{120}$ See Walpole's letter to Hume in Letters, 1: 284-5.

${ }^{121}$ David Hume, The History of England: From the Invasion of Julius Caesar to the Revolution in 1688, 6 vols. (Indianapolis, 1983), 1: 3-4.
} 
the footnote on the historical pyrrhonist controversy in "Of Balance of Power" and his defense of the "critical art" in "Of Populousness" in the 1760s.

The philosophical approach to history might in the end have "defeated" erudition in the eyes of public opinion by the middle of the eighteenth century. Hume's change of stance over the 1750s and 1760s may have been part of that campaign or a reaction to it (or both). However, as shown above, vanquisher and vanquished had much more in common than is usually assumed: the académiciens were discussing in the 1720s questions that would become central to Hume two decades later. And it was not just Hume among the philosophical historians who had ties to erudite scholarship: if, for instance, the participation of the Commons in the Saxon Wittenagemot was relevant to Hume's theory about the ancient English constitution (or rather its inexistence), so was the feudal or Roman origin of the French monarchy to Montesquieu's politics or the details of Roman, Greek and Mosaic heroic societies to Giambattista Vico's "rational civil theology of divine providence," to mention just three of the philosophical historians. ${ }^{122}$ If anything, Hume was the least erudite of the three, and this article has shown that his debts to erudite historians cannot be ignored.

We conclude, then, that Enlightenment philosophical history in general had much closer ties to erudite scholarship than was previously believed. The reaction of mid-eighteenth-century philosophical history against erudition is, in a sense, akin to that of an embarrassed teenager trying to hide his parents from his cool friends. Their grand enlightened narratives about the whole course of human history would not look so cool if they were shown to have been drawn from the nittygritty stuff of old-fashioned erudite historical enquiry. But the connection is undeniably there. This puts the Enlightenment closer to the more scholarly seventeenth-century Republic of Letters. Crucially, it puts them closer by stressing not the continuities, but the changes late seventeenth-century and early eighteenthcentury scholars submitted themselves to: there still is an Enlightenment that is markedly different from the intellectual world that preceded it, but it came into existence from forces within, not without.

Acknowledgements. This article is an outcome of research supported by the Coordenação de Aperfeiçoamento de Pessoal de Nível Superior (Capes), Ministry of Education, Brazil, Finance Code 001 (88881.129484/2016-01). I would like to thank Prof. John Robertson and the three anonymous reviewers for their substantial and insightful comments.

\footnotetext{
${ }^{122}$ On Montesquieu see Sylvana Tomaselli, “The Spirit of Nations,” in Mark Goldie and Robert Wokler, eds., The Cambridge History of Eighteenth-Century Political Thought (Cambridge, 2006), 9-39, at 10-14; and Michael Sonenscher, Before the Deluge: Public Debt, Inequality, and the Intellectual Origins of the French Revolution (Princeton, 2007), 131-49. On Vico's "rational civil theology of divine providence as a method" see Robertson, The Case for the Enlightenment, 201-55.
}

Cite this article: Faria P (2021). David Hume, the Académie des inscriptions and the Nature of Historical Evidence in the Early Eighteenth Century. Modern Intellectual History 18, 299-322. https:/doi.org/ $10.1017 /$ S1479244319000404 